\title{
The Use of Land as a Collateral Security for Credit in Nigeria: Problems \& Challenges
}

\author{
Jacob Otu Enyia ${ }^{1^{*},}$ Udungeri, Kevin ${ }^{2}$ \\ ${ }^{I}$ Senior Lecturer Faculty of Law, University of Calabar, Calabar, Nigeria \\ ${ }^{2}$ Lecturer, Faculty of Law, University of Calabar, Calabar, Nigeria
}

*Corresponding Author: Jacob Otu Enyia, Senior Lecturer Faculty of Law, University of Calabar, Calabar, Nigeria

\begin{abstract}
The focus of this work is the examination of the problems and challenges associated with the use of land for as a collateral security for credit, especially as security of the interest of a mortgage and how far it can be guaranteed in Nigeria.

The paper explores the meaning of the term land, mortgage, its nature and creation as provided for under the relevant laws. It also examine the nature of Mortgagor's security on the mortgaged land and the effect of the Land Use Act on the mortgaged land.

An appraisal was also carried out of the efficacy of mortgage transaction within the provisions of the Land Use. The consent provisions, revocation and compensation all under the provisions of the Land Use Act were looked at in.

It was identified that the nature of a right of occupancy as a statutory lease almost a right sui generis and different from the lease at common law. Also, it is possible to have an efficient mortgage transaction under the Act if and only if challenges and vacuums created by the Act can be filled. More so, outright utilization of land a collateral security without perfection is effort in futility.
\end{abstract}

Keywords: Secured Credit, Mortgage, Real Estate, Legal Mortgage, Right of Occupancy, Mortgage Land, Mortgage Security.

\section{INTRODUCTION}

In financing major economic activities, the use of credit by entrepreneurs, corporate entities and multinationals as a means of sourcing for capitals is by means of borrowing.Creditors then must be assured of getting back the loan advanced (borrower's capacity to repay the loan). This leaves us with a situation of secured and unsecured credit. A creditor who obtains security for any credit given is assured of a greater control over his debtor. ${ }^{1}$ Real and personal security are the main types of security recognized by law and each type as well, has its own classification with definite characteristics features in terms of its creation and enforcement. ${ }^{2}$

From the above, it flows therefore that security may be classified in terms of its subject matter (the nature and characteristics of each subject matter may determine the type of security to be created). ${ }^{3}$ Different subject matter can be used to secure credit. Where immovable property like land is used as security for credit, the way of enforcement will differ from using chose in action or other subject matter as guaranty for repayment of loan. All the different subject matter that can be used as security for credit facility go with it own challenges of enforcement in cases of default, the challenges that goes with the use of land by a borrower (mortgagor) as security for credit from a lender (mortgagee).

In the course of doing justice to this work, we examined the concept of mortgages, its mode of creation and its characteristic attributes. We x-rayed the operation of mortgage transactions under the

\footnotetext{
${ }^{1}$ Pedrazzini and Sampson: "The Legal Framework for secured credit: a suitable case for treatment" (1999) B.I.I Issue 1, page 127 at 129 quoted from Nigerian law of secured credit: I.O. Smith, 2001 at page 2

${ }^{2}$ I.O. Smith op.cit page 8 .

${ }^{3}$ I.O. Smith op.cit page 11.
} 
Nigerian Land Law system with reference to the Land use Act. ${ }^{4}$ An attempt was made to test the efficacy or efficiency of the use of land for mortgage transactions under the relevant laws.

In Nigeria today, the presentation and deposit of certificate of occupancy by a customer with a Bank is regarded as important and a prerequisite for mortgage loans. This security is often believed to by the bank as a worthy document of title and therefore, a worthy security for the loan or credit

\section{MORTGAGES}

In the first instance, a writer ${ }^{5}$ had said that -

"Land is today the most acceptable form of security, as it appreciates in value unlike other forms of security, over a period of years. It is often applied as security by way of mortgage (legal or equitable)"

The term mortgage according to the Black's Law Dictionary ${ }^{6}$ is a conveyance of title to property that is given as security for the payment of a debt or the performance of a duty and that will become void upon payment or performance according to the stipulated terms.

Although Lord MacNaghten in Samuel vs. Jarrah Timber and Wood Paving Corporation ${ }^{7}$ had pointed out that "No one ... by the light of nature ever understood English mortgage of real estate", several definitions have been proffered to this concept. According to Professor I. O. Smith ${ }^{8}$ relying on the words of Lord Lindley M. R. in Santley vs. Wilde ${ }^{9}$, defined a mortgage as a legal or equitable conveyance of title as a security for the payment of debt or the discharge of some other obligation for which it is given subject to a condition that the title shall be re-conveyed if the mortgage debt is liquidated.

Chesire ${ }^{10}$ opined that a mortgage arises where land is conveyed or otherwise dealt with in order to secure the payment of a debt or the discharge of some other obligation.

According to Megarry, the essential nature of a mortgage is that it is a conveyance of a legal or equitable interest in property with a provision for redemption ${ }^{11}$.

Although, a mortgage can be created over land or chattel, land provides a much more reliable and invaluable security for loans and advances in modern times. Physical control of the property is hardly necessary and its characteristic feature of immovability affords the creditor a reassuring grip on the security ${ }^{12}$.

Mortgage of land entails transfer or conveyance of title or interest in land by a debtor or a third party to the creditor as an assurance for repayment of debt or discharge of any obligation. Mortgage is different from other form of credit, for example, transfer of possession to the creditor which a pledge entails, or a mere passive right of retention, which lien entails. An ingredient of mortgage is that the lender acquires ownership and borrower retains possession, this place a great advantage on mortgage as opposed to pledge, since borrower keeps possession of the property for the time being.

The Land use Act does not stipulate how a mortgage shall be created. It rather preserves the existing laws on mortgages ${ }^{13}$. In the early days of Common Law, creating mortgages was through pledges. Lenders enter into possession of the land and take rents and profits either in discharge of both the principal and interest (called VivumVadium) or living pledge (since it automatically discharged the

\footnotetext{
${ }^{4}$ Cap L2 Laws of the Federation of Nigeria, 2004, referred to as "the Act". Until 1978 when the Act was promulgated, there was no uniform legislation regulating land tenure system in Nigeria. The North had the land Tenure Law while there were different customary and state Laws.

${ }^{5}$ H.S.N. Okoli: The Certificate of Occupancy as security for Bank lending, A Blueprint for Nigerian Law: Collection of critical essays written in commemoration of the thirteenth anniversary of the establishment of the Faculty of Law of the University of Lagos, edited by AkintundeObilade.

${ }^{6}$ Eighth Edition: Bryan A. Garner at 1031

${ }^{7}$ (1904) AC 323 at page 362

${ }^{8}$ I.O. Smith, Practical Approach to Law of Real Property in Nigeria 1999. Page 236.

${ }^{9}$ (1899) Ch. 474.

${ }^{10}$ Cheshire, The Modern Law of Real property. ( $9^{\text {th }}$ Edition) page 547.

${ }^{11}$ Megarry, A manual of law of Real property. ( $4^{\text {th }}$ Edition) page 460

${ }^{12}$ I. O. Smith, op. cit, page 236

${ }^{13}$ Section 48, Land use Act, Abioye vs. Yakubu (1991) 5 NWLR pt.190, p.130.
} 
entire debt) or in discharge of the interest only (called "MortumVadium" or dead pledge since it did not affect the gradual liquidation of the debt) ${ }^{14}$. "The chief distinction between a mortgage and a pledge is that by a mortgage, the general title is transferred to the mortgagee, subject to be re-vested by performance of the condition; while by a pledge, the pledgor retains the general title in himself and parts with the possession for a special purpose. By a mortgage the title is transferred; by a pledge the possession" 15

However after ${ }^{16}$, Mortgagors started conveying title in fee simple to mortgagees on condition that upon repayment of the loan on the agreed date, the conveyance to the mortgagee became annulled and the mortgagors are free to re-enter. But in the event the mortgagor could not repay the loan on the agreed date, the mortgagor's interest in the land will be extinguished and the title hitherto conveyed to mortgagee becomes absolutely vested in the mortgagee.

Equity was however later developed to intervene due to the harsh implications of strict application of the Common Law principle. A right to redeem in equity arises as soon as the mortgage is created to protect the mortgagor when his contractual right to redeem at Common Law is lost upon failure to repay on due date. ${ }^{17}$

Under the creation of mortgages in more modern times, we would consider

a) The mode of mortgage intended, that is: (i) Legal or (ii) Equitable;

b) The nature of interest involved - (i) Free hold (ii) Leasehold

c) The applicable law: (i) Common Law (ii) Property and Conveyancing Law ${ }^{18}$

d) The Land Use Act.

\subsection{Legal Mortgages}

Creating a legal mortgage may involve a freehold or leasehold interest ${ }^{19}$ whether under the Common Law, the Property and Conveyancing Law (referred to as "the PCL") or the Land Use Act (referred to as the Act") Act. At Common Law, legal mortgages are created on a freehold interest either by transfer or conveyance of the whole mortgagor's interest to the mortgagee. Mortgage transactions on leasehold interest are by way of assignment.

Under the PCL, Legal Mortgages are created on a freehold interest by granting of a lease by the mortgagor to the mortgagee, since outright conveyance of the whole legal estate in a mortgage is disallowed ${ }^{20}$. However, mortgages on leasehold interest under this PCL regime is by way of creating a sublease in favour of the Mortgagee ${ }^{21}$.

Generally however, whether the mortgagor has a freehold or leasehold interest in the property, he may create a charge by deed expressed to be by way of legal mortgage ${ }^{22}$.

The Act came in 1978 to modify drastically the form and modes of creating legal mortgages. It ${ }^{23}$ swept away all unlimited interest on land substituting therefore a Right of Occupancy. All interest in land like freehold and leasehold as understood under the Common Law has been substituted for a usufruct right ${ }^{24}$. Hence under PCL states, reference is made to subleases or sub lender leases of interests for the hitherto freehold or Leasehold or leasehold estates. ${ }^{25}$ While for conveyance or

\footnotetext{
${ }^{14}$ I .O. Smith op. cit, page 243

${ }^{15}$ Black's Law Dictionary: Eighth Edition, Bryan A. Garner at page 1031

${ }^{16}$ In the $15^{\text {th }}$ century

${ }^{17}$ This intervention by equity has developed the concept of EQUITABLE RIGHT OF REDEMPTION.

${ }^{18}$ PCL Cap100 Laws of Western Nigeria, 1959 being applicable in Oyo, Ondo, Ogun and old Bendel State.

${ }^{19}$ The doctrine of Estates which deals with Freehold and Leasehold Estates is beyond the scope of this paper.

${ }^{20}$ Section 108 PCL, 1959.

${ }^{21}$ Id. Section 109

${ }^{22}$ Id. Section 110

${ }^{23}$ Sections 1, 5 and 6, Act

${ }^{24}$ Usufruct right gives its holder the right to use land, manage and benefit from its income just as the owner. The tern can be maximum of 100years for entitles and a lifetime for individuals. The right is established by registration with the land registry.

${ }^{25}$ Section 23, Act
} 
assignment of freehold or leasehold estates of Common Law states are substituted for Assignment or both $^{26}$.

\subsection{Equitable Mortgage}

Unlike Legal Mortgages, there is no variation amongst the states in Nigeria as to the creation of an equitable mortgage. Equitable mortgages are created in anyone of the following ways:

a) Where mortgagor has only an equitable interest, he creates equitable mortgage. A legal mortgagor at common law can create a second mortgage over the same property in favour of a subsequent mortgagee $^{27}$

b) Where there is an agreement to create a legal mortgage - An equitable mortgage by way of an agreement to create a legal mortgage is different from an equitable charge. Whilst equitable mortgage creates an estate which might be vested in the mortgagee under a legal mortgage by suing in equity for specific performance, the equitable charge simply gives a right to payment out of the property. ${ }^{28}$

c) By delivery of title deeds with requisite intention to create a mortgage. ${ }^{29}$ In African Continental Bank Ltd. V. Yesufu the court held that, the mere deposit of title deed with a bank will not constitute the bank and mortgagee; the borrower shall sign a memorandum under seal contemporaneously with the delivery of the deed. ${ }^{31}$

d) By operation of law ${ }^{32}$.The court may also infer a mortgage relationship.

\subsection{Creation of Mortgage under the Land Use Act}

Under the Act, the Conveyance of fee simple is no longer possible because the Act has swept away (so to speak) all unlimited interests on land ${ }^{33}$.Therefore unlike the PCL, the Act did not provide for how a mortgage shall be created but rather, it preserves the existing law on mortgages subject to such modifications as will bring those laws into agreement with the Act or its general intendments. ${ }^{34}$.

The Act prohibits the alienation of a customary right of occupancy without the consent of the Local Government ${ }^{35}$.The provision appears to apply to actual grants of customary rights of occupancy over land in non-urban areas. This is because by virtue of the provisions of Section 36 (5) of the Act, all land in non- urban areas the subject matter of customary right of occupancy deemed granted by the Local Government are inalienable so that the requirement of consent is irrelevant. ${ }^{36}$

\subsection{Nature of Mortgagee's Security on the Mortgaged Land}

As regards the nature of mortgage security on the mortgaged land, the law will regard a mortgagee as the legal owner of the mortgaged land in an agreement to convey legal title to a mortgagee although in equity, the real owner is the mortgagor; the mortgagor is seen as a beneficial owner whose interest in the property is merely as a security for the loan advanced to the mortgagor ${ }^{37}$ During the existence of the mortgage, the mortgagee preoccupies himself with the protection and maintenance of the security and ensures that the title conveyed is not in any way defective, rendered useless or any encroachment by a third party. ${ }^{38}$ This is because he must be able to have a good security to fall back on in event of default by the mortgagor.

\footnotetext{
${ }^{26}$ Ibid

${ }^{27}$ I.O. Smith at page 41

${ }^{28}$ I.O. Smith, op.cit. at page 41

${ }^{29}$ This method is perhaps most rampant. In practice, the delivery is accompanied by a memorandum which allows the mortgagee to deal in the property. I.O. Smith, op. cit.

301977 NCLR, page 212

31 Page 212

${ }^{32}$ See I.O. Smith, op. cit, for more detailed discussion on this means of creating equitable mortgages.

${ }^{33}$ Section 1, 5 of the Act

${ }^{34}$ I.O. Smith, op. cit.

${ }^{35}$ Section 21 of the Act

${ }^{36}$ I.O. Smith, op. cit. page 46. See also the age old case of Savannah Bank V. Ajilo 19891 NWLR, Part 96, where the apex court held that, all statutory rights of occupancy were caught by the consent provisions and that failure to obtain Governor's consent rendered the mortgage transaction void.

${ }^{37}$ I.O. Smith, op. cit at page 60

${ }^{38}$ I.O. Smith, op. cit
} 


\subsection{Enforcement of Mortgage Security}

Although the primary consideration for every credit transaction is the credit worthiness of the debtor, however, security is taken on a second thought, as it were ${ }^{39}$ to serve as an assurance of having a property to fall back on upon mortgagor's default. I.O. Smith highlighted the following methods of enforcing mortgage security:
a. Enforcement of covenant to repay
b. Entering into possession
c. Sale of Mortgage property in satisfaction of mortgage debt.
d. Appointment of a receiver
e. Foreclosure of equity of redemption ${ }^{40}$.

The repayment covenant is an ordinary contract. The mortgagee may sue for repayment any time after the expiry of the repayment period. More so as the lease granted is a security; the mortgagee will normally not take advantage of it. He may do so, however, in order to keep down interest on the loan by paying himself out of the rents and profits arising from the land. But the court will exercise stringent supervision over him; he is strictly accountable, not only for what he actually receives, but also for what he ought to have received by the exercise of due diligence.

\section{The Right To SELL}

Furthermore, under certain conditions, he has a statutory power to sell the whole of the mortgagor's interest in the land. He is not allowed to keep any surplus proceeds arising from the sale. He owes (similar to a trustee) a duty of care to the mortgagor; he has to obtain a reasonable price for the land. Again, with a view to obtaining repayment of the interest, the mortgagee may exercise a statutory power of appointing a receiver to receive on his behalf the rents and profits arising from the land. The receiver is deemed to be the agent of the mortgagor, and the mortgagee thus avoids the disadvantage of strict accountability to which, if he were to enter into possession, he would be subject.

On the equitable right of foreclosure, if a debt be unpaid for an unreasonable time beyond the agreed repayment period, the mortgagee may foreclose by obtaining an order of the court that the land shall become his unless payment in full is made by a certain date.

The order becomes 'absolute' and the mortgagor loses all rights to the land unless he can persuade the court to reopen the order at a later date.

\subsection{Effect of Land Use Act on Land as a Credit Security}

It is no longer news in Nigeria that after 1978 (the advent of the Land Use Act) no individual in the country or state has absolute ownership or what could be called interest in fee simple ${ }^{41}$. Furthermore, Section 9 of the Act gives the Governor of a State power to issue a Certificate of Occupancy to either holder of statutory or customary rights of occupancy ${ }^{42}$. "Right of occupancy is the main conveyance of the interest, the certificate of occupancy merely evidences title. The latter is a confirmation of the former, ${ }^{, 43}$

In other words, all an individual can lay lawful claim to now is a statutory right in the landed property ${ }^{44}$. But what exactly a Right of Occupancy is, the Act does not define. ${ }^{45}$ Although it can be

\footnotetext{
${ }^{39}$ NojeemAkinjide AMODU, an Associate in the Firm of Rouq\& Co. Security only forms second consideration in credit transactions.

${ }^{40}$ The methods are cumulative and not exclusive such that after the adoption of one method the debt remains unsatisfied, mortgage may adopt another. However, where foreclosure proceedings are embarked upon by the mortgagee, he cannot afterwards fall back on any of the other methods earlier mentioned above. Se also, htt:/peisker.net/mortgages.htm

${ }^{41}$ By virtue of Section 1 of the Act, all Lands are vested in the governor of a state and individuals only enjoy a Right of Occupancy, whether granted or deemed.

${ }^{42}$ H.S.N. Okoli, op.cit at page 224.

${ }^{43}$ Per Ndoma-Egba J.C.A in Haruna V. Ojukwu 1991 7NWLR, Part 202 at 225, quoted from H.S.N. Okoli, op. cit.

${ }^{44}$ Abioye vs. Yakubu, supra.
} 
deduced and placing reliance on its precursor, the Right of Occupancy is usufruct, its exact legal nature remains obscure. Is it a Lease, a license or a Freehold? ${ }^{46}$

Knowing exactly its legal nature is very important to a mortgagee who wants to accept same to guarantee the repayment of his loan. He should know exactly the value or weight of what the mortgagor is willing to give him as security.

Before we continue to examine the true nature of a right of occupancy, perhaps we should at this juncture state that the Act creates two types of Right of Occupancy:

1. Customary Right of Occupancy; and

2. Statutory Right of Occupancy. ${ }^{47}$

A granted statutory right of occupancy is for a term certain ${ }^{48}$ although there is no requirement of such certainty of term when it is deemed. Moreso, although a grantee of a statutory right of occupancy is required to pay rent for the land $\mathrm{d}^{49}$ there is no such requirement for a grantee of a customary right. A holder of granted customary right may only have a fixed term and pay rent if he applies (under section 9 (1) (b) for a Certificate of Occupancy. ${ }^{50}$

It is settled however, that a grantee of a Right of occupancy (whether actual or deemed) has "exclusive right to the land the subject of the statutory right of occupancy against all persons other than the Military Governor. ${ }^{, 51}$ For this provision, a right of occupancy has been likened to a lease not a licence or a freehold interest.

The Supreme Court in the case of Abioye vs. Yakubu ${ }^{52}$ at page 223 said -

"Rights of Occupancy beat resemblance to leasehold interests. They can be assigned. They can be mortgaged and they can be underlet or sublet." But is a Right of Occupancy indeed a lease? The best way to answer this would be to compare in attributes the features of both a lease and a Right of Occupancy".

A learned Professor of $\mathrm{Law}^{53}$ has argued that a holder of a lease must have an exclusive right of exclusive possession but that under the Act, the holder of a Right of Occupancy shares his right with the State Governor (who enjoys certain rights on that land concurrently with him), hence a major requirement for a lease is lacking in a Right of Occupancy.

In the creation of a lease, it has been stated that rent must be reserved. ${ }^{54}$ We have stated in the course of this paper that a grantee of a right of occupancy is like a leaseholder.

It is trite law that in the creation of a lease, there must be certainty of term not only in terms of its commencement, duration but also its termination. ${ }^{55}$ This requirement of a lease has also been satisfied under the Act in respect of a holder of a Right of Occupancy ${ }^{56}$, As a matter of fact, the Supreme Court in Savannah Bank Ltd vs. Ajilo ${ }^{57}$ said:

"In terms known to interests in land, the quantum of a... right of occupancy remains unclear. To the extent that it can only be granted for a

\footnotetext{
${ }^{45}$ But a precursor, the Land Tenure Hold (of Northern Nigeria) defines it as "a title to the use and occupation of land."

${ }^{46}$ NojeemAkinjideAmodu, op. cit

${ }^{47}$ Both could be granted by the Governor either actually or deemed to have been granted by him.

${ }^{48}$ Section 8 , Act.

${ }^{49}$ Section 5 (1) (c), Act.

${ }^{50}$ Section 8, 10(b), 14 of the Act. See also EnefiokEssien: Land Use Act Security in Real Estate in Nigeria, contained in Land Use Act: 25 Years After, (2003) I. O. Smith (ed.)pg 279 @ 282.

${ }^{51}$ Section 14, Act.

${ }^{52}$ Supra

${ }^{53}$ EnefiokEssien, op.cit, page 283

${ }^{54}$ There are plethora of authorities now to the effect that a rent free lease in possible See for instance Onyeguchi vs. shadiac (1988) 1 ALL NLR 18 @ 15

${ }^{55}$ United Bank Africa vs. Tejumola (1986) 4 NWLR (Pt. 38) p.815

${ }^{56}$ Supra, reference 28.

${ }^{57}$ (1989) INWLR (pt 97) 305
} 
specific term under S.8 Land Use Act, 1978, it has the resemblance of a lease."

Although there is the phenomenon of running leases (i.e. leases which last till terminated by notice on either side), it has been said that deemed statutory right, granted customary right and deemed customary right have no certainty of term and would fail as a lease under Common Law.

Furthermore on our comparative analysis of a Right of Occupancy and Leasehold, it is our belief that the ease with which a right of Occupancy can be revoked by the Governor is suggestive of it not capable of a lease ${ }^{58}$. Under section 28 of the Act

\section{"It shall be lawful for the Military Governor to revoke a right of occupancy for overriding public interest."}

The Right may also be revoked if the land is required "for public purpose"

The problem here actually is on how nebulous and extremely elastic the term "public purposes" or "public interest" may be interpreted. This does not portray the Right of Occupancy as an adequate or efficient security for a mortgagee.

So, if the Right of Occupancy under the Act is not a lease at Common Law, what exactly is it? A license? It cannot be license because its alienable, transferrable and transmissible interest in land ${ }^{60}$. The Right of Occupancy is also not a Freehold interest since the holder has neither exclusive right of possession nor the absolute owner. ${ }^{61}$

The Right of Occupancy has been viewed as Sui generic interest ${ }^{62}$ in land more appropriately called a statutory lease. This view appears to have been supported by Nigerian courts as the Court of Appeal in L.S.D.P.C vs. Foreign Finance Corporation ${ }^{63}$ held that:

"The right of occupancy is in nature a hybrid between a licence and a lease... on terms and conditions which upon breach by a right holder in subject to revocation by the governor"

\subsection{The Potency of Mortgage of Land as a Form of Credit in Nigeria}

The word "potency" may be defined as, effectiveness, strength, power etc. However, the New Webster's Dictionary of the English language International Edition (1993) defines "potency" as the state of quality of being potent. The same dictionary also defines 'potent' as strong, powerful. From the definition, we can safely put the topic as the effectiveness of legal mortgage of land as a form of security in Nigeria.

In the Nigeria of today, the worth placed on land and its value cannot be overemphasized. This is due to the increasing value and appreciation of the land loan. There is this assurance that it would not lose out.

As earlier discussed, in the mortgage of land as a form of security, the mortgagor has two types of rights, one legal and the other equitable. There is his legal right to redeem on a specified date and there is also his equitable right, exercisable any time thereafter. It should be noted that until the legal date for redemption passes, the power of sale has not arisen ${ }^{64}$.

A case to consider is the case of Savannah Bank (Nig.) Ltd. v.Ajilo ${ }^{65}$, the Plaintiff executed a deed of mortgage dated $5^{\text {th }}$ September, 1980 in favour of the $1^{\text {st }}$ Defendant. Upon default by the Plaintiffs, the

\footnotetext{
${ }^{58}$ EnefiokEssien, Op. cit, pages 285-285.

${ }^{59}$ Section 28(4) Act.

${ }^{60}$ Section $21,22,24, \& 34$ Act

${ }^{61}$ However, it is worthy of note that the deemed statutory right, granted customary right and deemed customary right share certain features of a freehold, i.e. a rent-free right and indefinite term.

${ }^{62}$ EnefiokEssien. Op. cit, page 288

63 (1987) I.N.W.L.R. (pt50) 413 @ 444. See also Osho vs. Foreign Finance Corporation (1991) 4. N.W.L.R. (pt 184) $157 @ 197$

${ }^{64}$ Honourable Justice S. A. Oduwole (RTD) in his book land masters through the case at chapter 16 page $85-$ 86.

${ }^{65}$ (1995) 4 NWLR part 390 pg 379
} 
$1^{\text {st }}$ Defendant sought to sell the property involved by advertising the Auction sale. The Plaintiffs sued for declaration that the Deed of Mortgage was void and also that the Auction Notice was also void. The grounds of the action were that -

a) The property involved was situated in an urban area in Lagos;

b) The property was already vested in the $2^{\text {nd }}$ Plaintiff before the Land Use Act 1978 came into force;

c) By section 22 of the Land use Act, the consent of the Governor of Lagos State ought to be first sought and obtained before the execution of the Deed of Mortgage and also the Public Auction; and

d) As no consent was sought as aforesaid both the Deed of Mortgage and the Auction Notice were void.

The contention of the Defendants on the other hand was that the provision of Section 22 of the Land Use Act did not apply to land being held before the coming into effect of the Land Use Act. Section 1, 22, 26 and 34 of the Land Use Act 1978 were considered and it provides as follows -

Section $1 \quad$ Subject to the provisions of this Decree all land comprised in the territory of each state in the Federation are hereby vested in the Military Governor of each state and such land shall be held in trust and administered for the use and common benefit of all Nigerians in accordance with the provisions of the Decree.

Section 22 It shall not be lawful for the holder of a statutory right of occupancy granted by the Military Governor to alienate his right of occupancy or any part thereof by assignment, mortgage, transfer of possession, sub-lease or otherwise howsoever without the consent of the Military Governor first has and obtained.

Section 26 Any transaction or any instrument which purports to confer or vest in any person any interest or right over land other than in accordance with the provisions of this Decree shall be null and void.

Section 34. (1) The following provisions of this section shall have effect in respect of land in any urban areas vested in any person immediately before the commencement of this Decree.

(2) Where the land is developed the land shall continue to be held by the person in whom it was vested immediately before the commencement of this Decree as if the holder of the land was the holder of a statutory right of occupancy issued by the Military Governor under this Decree.

(3) In respect of land to which subsection 2 of this section applies there shall be issued by the Military Governor on application to him in the prescribed form a certificate of occupancy of the Military Governor is satisfied that the land was immediately before the commencement of this Decree vested in that person.

The Plaintiffs succeeded in the High Court and the Defendants appealed to the Court of Appeal; the appeal was dismissed. Being dissatisfied with these judgments, the Defendants further appealed to the Supreme Court but the Supreme Court Justices unanimously dismissed the appeal.

Obaseki J.S.C who presided and delivered the lead Judgement observed that the appeal was "probably one of the earliest of contested matters that will bring the revolutionary effect of the Land Use Act to the deep and painful awareness of many." (emphasis mine)

Obaseki J.S.C. at page 329 said -

"In my view and I agree with Chief Williams expression of anxiety over the implementation or consequences of the implementation clauses in the decree, it is bound to have suffocating effect on the commercial life of the land and house owning class of society who use their properties to raise loans and advances from the bank. I have no doubt that it will take the whole working hours of a state Military Governor to sign consent papers (without going half way) if these clauses are to be implemented. These areas of Land Use Act need urgent review to remove their problems. 
A distinction was made between a deemed grant and an actual grant. A deemed under the Land Use Act is a grant by operation of law. It was decided that the holder of a statutory right of occupancy granted by the Military Governor as contained in Section 22 of the Act includes implied grant in Sections 34(2) and 36(2) of the Act. Any failure by a holder under Sections 34(2) or 36(2) of the Act to comply with the provisions of Section 22 would attract the full rigour of section 26 of the Act and render a transaction or an instrument arising out of it void.

One of the issues canvassed in the Ajilo case is whether the $1^{\text {st }}$ Defendant required the written consent or consent in writing previously obtained to mortgage his property called the mortgaged property to the $1^{\text {st }}$ Appellant having regard to the fact that the property was vested in the $1^{\text {st }}$ Plaintiff before the commencement of the Land Use Act 1978.

According to Fidelis Oditah ${ }^{66}$ while discussing the issues and problems in corporate debt financing in Nigeria noted that the decision in Ajilo's case put to rest an argument first developed by Omotola ${ }^{67}$ that a mortgagor or other alienation of a statutory right of occupancy deemed to be granted by the Governor did not require Governor's consent.

Fidelis Oditah went further to note that in Ajilo's case, the mortgagor on whom the obligation to obtain consent was imposed by the Act obtained a declaration that the mortgage was void for want of consent. The consequence being that he obtained money from the bank which now had no security. He noted that the case did not however decide that the personal obligation of the mortgagor to repay the loan was void, only the security was invalid. Fidelis Oditah also stated that Ajilo's case illustrates with startling clarity, one of the pitfalls of legal mortgage on land.

In the case of Awojugbagbe Light Ind. Ltd v. Chinukwe ${ }^{68}$ however, the issue considered was the validity of a loan and mortgage agreement when the mortgagee performed his obligation under the agreement by lending to the mortgagor the sum of $\mathrm{N} 215,000.00$ and the mortgagor changed by way of first legal mortgage his property, No 60 - 64 Ijebu Road, Ibadan as security for the loan before the Governor of Oyo State gave his consent for the mortgage under Section 22 of the Land Use Act. It was held that the holder of a statutory right of occupancy is certainly not prohibited by Section 22(1) of the Land Use Act 1978 from entering into some form of negotiations which may end with a written agreement for presentation to the Governor for his necessary consent for approval.

Bello J. C. N., delivering the lead judgment distinguished this case from Ajilo's case he noted that -

"the controversy in this instant case does not revolve on lack of consent but on consent given after the execution of the mortgage deed"

Thus, he held that to hold that a contravention of or non-compliance with Section 22 of the Act occurs at the time when the holder of a statutory right of occupancy executes or seals the deed of mortgage and will be contrary to the spirit and intendment of Section 22 of the Act.

\section{EfFect Of The Provision Of ACt ON The Mortgagee's InTERest In LAND}

The relevant questions are what are the effect of the provisions of the Act on mortgage transactions? Toput it more plainly; how secured is a mortgagee's interest in land in a mortgage transaction in the face of the provisions of the Land Use Act.

This would be examined under three major headings

a) Consent provisions;

b) Revocation and Compensation; and

c) Certificate of Occupancy.

\subsection{Consent Provisions ${ }^{69}$}

By virtue of Section 21 of the Act, the approval of the Local Government is required for any alienation by way of assignment, mortgage; transfer of possession or sublease of a customary right of

\footnotetext{
${ }^{66}$ Contemporary issues in Nigerian Law: Chapter 8 Pg 129

${ }^{67}$ Essay on the Land Use Act 1984pg 27

${ }^{68}$ (1995) 4 NWLR part 390 pg 379

${ }^{69}$ Section 26 of the Act provides that transaction without the requisite consent is null and void.
} 
occupancy $^{70}$. Under section 22(1) (a) of the Act, it appears to be discretional whether to ask for consent to an equitable mortgage ${ }^{71}$ or not since it seems to contemplate the possibility that an equitable mortgage might be created without consent.

Perhaps before we proceed, it is pertinent at this juncture to elucidate more on some of the consent provisions:

Paragraph (a) of Section 22(1) of the Act is to the effect that where an equitable mortgage has been previously created with the consent of the governor, consent will not be required for a legal mortgage thereon. This rather implies that equitable mortgages also require the consent of the Governor.

An equitable mortgage can be created by mere deposit of title deeds where the deposit was done with the intention to be used as security, mere agreement to execute a legal mortgage, the use of Form 15 in the Registration Area, and the use of equitable interest in land to secure a debt. An equitable mortgage transfers interest to the mortgagee nonetheless equitable. Though equitable, it is an interest in land and falls within the purview of Section22 of the Act. It has been argued that if the nature of interest anticipated under the Act must be legal, section 51 of the Act will not define mortgages to include equitable mortgage. ${ }^{72}$

Though it is acceptable that agreement to alienate a Right of Occupancy is not prohibited under Section 22 of the Act, it is not absolutely correct to say that deposit of title deeds with intention for the title deeds to be used as security for the loan is not alienation. To alienate is to transfer or convey a property to another. See Black's Law dictionary $\left(7^{\text {th }}\right.$ Edition). The equitable mortgagor undoubtedly transfers or conveys an equitable interest to the mortgagee. It must therefore be taken that the prohibition of alienation without the consent of the Governor refers to alienation of legal interest. This is because Section 22 provides for a duly executed approval of the lessor who is the holder of the statutory Right of Occupancy. See Section 21 of the Act.

Furthermore on consent provisions, Section 24(b) of the Actprovides that the interest of an occupier can only devolve on the beneficiaries wholly without any divisions. The implication of this is that the division of land can only be validly made with the consent of the Governor. ${ }^{73}$

It must however be emphasized that the consent of the Governor is only required where the land subject matter of the right of occupancy is to be divided and where it is a statutory right of occupancy of an occupier. Thus, where the devolution does not entail division of the land but the whole of it, or the will is made by a holder and not an occupier or where it is a customary right of occupancy, the consent is not required for there to be a valid transfer by way of devolution as a will or devolution, under Customary Law is a transfer. See section 21 and 22 of the Act.

It is therefore unsafe for a mortgagee to accept statutory right of occupancy by an occupier who became vested by devolution upon the death of the original occupier as security for a loan unless he the mortgagor relying on devolution must have received the whole property and not as a result of partition of a larger land. Such security is liable to be voided for as little as the title was not properly conferred on the mortgagor, he cannot transfer a better title to the mortgagee ${ }^{74}$.

It should be noted however that the courts are not likely to be inclined to accede to a mortgagor seeking to void a mortgage because the title is defective under Section 23 of the Act. This is based on the principle that a person shall not be allowed to benefit from his own wrong. This has been settled in a plethora of authorities.

Another noticeable impact on mortgage transactions under this heading is what happens where the consent is obtained subsequent to entering into the mortgage transaction?

As an obiter dictum in Savannah Bank (Nig) Ltd vs. Ajilo ${ }^{75}$, the Supreme Court of Nigeria said consent must be obtained prior to the mortgage. However, in order to give a human face and protect

\footnotetext{
${ }^{70}$ Governor's consent/approval is required for same on statutory right of occupancy under section 22 of the Act.

${ }^{71}$ Section 50 (1) of the Act defines mortgage to include mortgages legal or equitable, second and subsequent.

${ }^{72}$ NojeemAkinjideAmodu, op. cit

${ }^{73}$ This is a strange requirement because it restricts the rights of a testator who is merely an occupier to give out his occupational rights in parts to several persons. This raises some crucial questions. (Who should obtain the consent? - beneficiary or testator), at what stage should the consent be obtained? Et cetera.

${ }^{74}$ NojeemAkinjideAmodu, op. cit

${ }^{75}$ Ibid at page 805 .
} 
the efficiency of mortgage transactions under the Act, the Nigerian courts have rather held such a mortgage transaction incohate rather than illegal or void. ${ }^{76}$ So, despite the mandatory statutory consent requirement, "first had and obtained", the courts have held it to means no more than that the mortgage transaction concluded becomes incohate (in complete) pending when the requisite consent is eventually sought and obtained. Departure from doing this would have drastically had a telling effect on efficiency of mortgage transaction in Nigeria. ${ }^{77}$

Another situation is where the requisite consent is not obtained at all. Here, the mortgage transaction is clearly null and void ${ }^{78}$. Then, what happens to a mortgagee, what is his fate, who has advanced a loan but on a mortgage transaction where consent was not sought and obtained. Does it mean he losses everything since the whole transaction is void?

The Nigeria judiciary again rose to the occasion and made a distinction between a null or void transaction on one hand and an illegal transaction on the other. The courts have had to ask whose duty it was to obtain the requisite consent. Found out to be mortgagor's (as the holder of the right of occupancy ${ }^{79}$ since mortgagee is expressly excluded under Section 51 of the Act). The courts have held (applying the principles of Equity) that he would not be allowed to plead a void transaction when he has benefited from same ${ }^{80}$ (the credit facility had already been enjoyed by the mortgagor). In the words of Akpata JCA,

"Apart from the principle of law involved it is morally despicable for a person who has benefitted from an agreement to turn round and say that agreement is null and void" ${ }^{\prime 81}$

Although it appears that judicial activism had cushioned the negative effects the Act would have had on mortgage transaction in Nigeria, there are still issues and problems which militate against a smooth mortgage transaction under the Act.

First, there is always delay in the Governor granting the consent. Also, while it is obligatory to obtain the Governor's consent to a landed security transactions such as that in mortgage transactions, there is no corresponding obligation on the Governor to give his consent when applied for, or to give it within a reasonable time or not to unreasonably withhold his consent, or to give his reasons in the event of refusing to give his consent. As a matter of fact, it has been said that an order of mandamus cannot compel the performance of a similar function of the Governor in approving mortgage transactions ${ }^{82}$.

\subsection{Revocation and Compensation}

Another major upsetting provision under the Act as it affects mortgage transactions is the definition given to a "holder" of a right of occupancy. A "holder" in relation to a right of occupancy means, "a person entitled to a right of occupancy" ${ }^{\prime 3}$. The unpalatable effect of this is that although the mortgagee may have been preserving his interest in the mortgage security (the right of occupancy and improvements there on), although he may even be ensuring periodic payment of stipulated rents, once the Right of occupancy is revoked, his security is gone and cannot attach automatically to the mortgagor's interest in any changed form. So, whereas, the mortgagor may be entitled to compensation for the value of his unexhausted improvements ${ }^{84}$ on the land, our dear mortgagee cannot lay claim to such compensation money. This is a major set-back in the efficacy or potency of using land for mortgage transaction under the Nigerian Laws.

\footnotetext{
${ }^{76}$ Awojugbagbe Light Industries Ltd vs. Chinukwe

${ }^{77}$ With this judicial activism, consent in this situation is retained as a "routine affair". See: Omotola, J. A:

"Interpreting the Land Use Act,." Vol 1, The Journal of Nigeria Law, (1992) p. 108.

${ }^{78}$ Section 26, Land Use Act

${ }^{79}$ F.B.N. PlcV. Songonuga, 2007 NWLR, Part 1021 page 239.

${ }^{80}$ Adedeji vs. National Bank of Nigeria (1989) INWLR (pt 96) 212, All. Gen. Federation vs. Sode (1990)

INWER (pt 128) 500, Solanke vs. Abed \&Anor (1962) ALLNLR (pt 1) 230 held No 4

${ }^{81}$ Mortgagor may be entitles to compensation for the value I id. At pp 266-227.

${ }^{82}$ See: Queen V. Minister of Land and Survey, Ex-parte, the Bank of the North (1963) CCHCJ 1617/73 @ 61.

${ }^{83}$ Section 50(1) of the Act expressly excludes a mortgagee from the definition of a holder

${ }^{84}$ Section 29 (1) and (2). Award of compensation to holders of undeveloped plots under the Land Use Act Case for reform: Uche J. Osimiri: Justice, A journal of contemporary legal problems, Vol. 3, Number 7.
} 


\subsection{Certificate of Occupancy ${ }^{85}$}

One other innovation introduced by the Act is the issuance of a certificate of Occupancy by the Governor of a state. It should be noted that a certificate of occupancy is merely an evidence of a right of occupancy for which it does not on its own confer a title or interest in land. The Act has not provided any conclusive means of proving ones entitlement to a right of occupancy.

The certificate raises a rebuttable presumptive right of occupancy ${ }^{86}$. In Azi v. Registered Trustees of The Evangelical Churches, ${ }^{87}$ the court held that the issuance of certificate of occupancy in respect of any land would not validate defects, if any in the title of the holder; thus, the court summed it up by saying that a certificate of occupancy granted to one of the claimants who has not proved a better title, was invalid. ${ }^{88}$

This means a certificate of occupancy may be set aside if it turns out that the holder had no right to the land ${ }^{89}$, or in favour of a pre-1978 conveyance or in favour of a deemed grantee of right of occupancy under section 34 of the Act ${ }^{90}$. From the dictum of His lordship, Nnameka-Agu, ${ }^{91}$ J.S.C, it can be inferred that a certificate of occupancy issued pursuant to the Act only gives the right to use and occupy land, it neither confers nor is it necessarily an evidence of title. Unlike a conveyance which is the means whereby a right in land arises, a certificate of occupancy confers no interest in land.

The horror and hellish implication of this is that where the certificate of occupancy is set aside due to any reason, the mortgagee who has accepted it as security realises he has burnt his own fingers. The certificate he is holding automatically becomes "a piece of paper having no value"

\section{CONCLUSION}

We have identified the nature of a right of occupancy as a statutory lease, almost a right sui generis and different from the lease at Common Law. We have also discussed mortgage transaction within its operations under the Land Use Act and we have pointed out certain setbacks and challenges which the Act portends for the efficiency of mortgage transactions.

Based on the said discussions, one could conclude that it is possible to have an efficient mortgage transaction under the Act if and only if the challenges and vacuums created by the Act can be filled. Efficiency of mortgage transaction under the Act is far from being a myth. However, it is also not in full realization. We believe that dynamic amendments in the Land Use Act (thanks to our court for having saved the situation this far with land mark judicial pronunciations) would go a long way to making the reality of an efficient mortgage transaction in Nigeria more glaring. The Act is long overdue for change, more so that it is a product of the Military regime.

Firstly, the Land Use Act should specify a time frame within which the consent of the Governor is to be given. This would avoid the delays associated with such consent giving process. More so, the Governor's should have a more potent means of verifying the claim to right of occupancy of any individual before the issuance of the certificate of occupancy. This would add to the value and weight of the certificate and probably make it a good root of title.

It is suggested that on the revocation of the right of occupancy subject matter of mortgagee's security, the Act should permit the mortgagee to have an equal right to claim the compensation money unlike the present situation.

Finally, we conclude that the efficiency of mortgage transactions under the Act is not in doubt. As a matter of fact, mortgage transactions go on every day in various financial institutions (Commercial

\footnotetext{
${ }^{85}$ The issuance of a certificate of occupancy is provided under section 9 of the Act.

${ }^{86}$ See: The Registered Trustees of the Apostolic church vs. Olowokemi (1987) 4 NWLR Pt 58, held No 4 (Sc), Ogunleye vs. Oni (1990) 2 NWLR (Pt 135) 745.

8719916 NWLR, Pt 195121.

${ }^{88}$ Ibid at page 126.

${ }^{89}$ Adedejivs Williams (1989) I NWLR (pt 99) 811.

${ }^{90}$ Sir AdetokunboAdemola vs. Amao\&Ors (1982) CGSLR p. 273 reported in Omotola J. A. "Cases on the Land Use Act" p. 132

${ }^{91}$ Ogunleye V. Oni, op. cit

${ }^{92}$ Per Belgore, JSC in Ogunleye vs. Oni, I.O. Smith, op. cit. at page 28. The effect is that, a Bank who takes the certificate of occupancy as security only gets a document of transfer but which in reality, transfers no interest in the land to the Bank.
} 
Banks, Mortgage Banks). However, for mortgage transactions in Nigeria to come to full realization as experienced in developed countries, amendments which differ from the current situation would have to be made.

As H.S.N. Okoli ${ }^{93}$ wisely articulated -

"An important point worthy of note is that before a Bank accepts only a certificate of occupancy as security for loan advances, it must ensure that the customer is in fact the person lawfully entitled to either statutory or customary right of occupancy over the land in question. This can only be done by a thorough investigation of the proposed debtor's root of title as provided in the perfection requirement. This is because in Nigeria today, the Latin maxim "nemodat non quod habet" still applies with all its rigours and the best kind of security in relation to land still remain a good root of title".

\section{AUTHOR'S BIOGRAPHY}

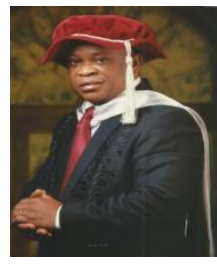

Dr. Jacob Otu Enyia is a Barrister and Solicitor of the Supreme Court of Nigeria and a senior lecturer in the department of Commercial and Industrial law in the University of Calabar, Calabar-Nigeria. He has authored so many Articles in both local and international journals and a specialist in Consumer Protection Law and Commercial Law. He is also developing and researching in the area of Telecommunications and Banking Law.

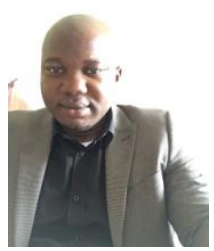

Kevin Ukeomure Udungeri is a Lecturer in the Faculty of Law, University of Calabar. Studied LL.B University of Calabar, BL Nigerian Law School, LL.M From the University of the west of England, Bristol, and currently a Ph.D researcher at the university of Leeds England.

Citation: Jacob Otu Enyia, Udungeri, Kevin. “ The Use of Land as a Collateral Security for Credit in Nigeria: Problems \& Challenges" International Journal of Managerial Studies and Research (IJMSR), vol 6, no. 7, 2018, pp. 44-56. doi:http://dx.doi.org/10.20431/2349-0349.0607005.

Copyright: (C) 2018 Authors. This is an open-access article distributed under the terms of the Creative Commons Attribution License, which permits unrestricted use, distribution, and reproduction in any medium, provided the original author and source are credited.

93 The Certificate of Occupancy as security for Bank lending, op. cit at page 232. 